\title{
ПРОБЛЕМЫ РАБОТЫ ВОЕННО-МОРСКОГО СОВЕТА В ГОДЫ ПРАВЛЕНИЯ КАРЛА І СТЮАРТА
}

Созданный в годы Генриха VIII Военно-морской совет стал органом, эффективно обеспечивающим постоянную работу английского военного флота. Во многом именно благодаря Совету превратившийся в государственный институт флот в эпоху Тюдоров успешно решал сложные задачи по обороне страны и обеспечивал реализациюее наступательной стратегии, тем самым заложив основу для превращения Англии в великую морскую державу.

Однако с восшествием на престол короля-миротворца Джеймса Стюарта это «любимое детище Тюдоров» стало объектом пренебрежения со стороны власти. В этих условиях коррумпированные служащие и высшие офицеры флота стали рассматривать разрушающуюся военно-морскую систему как источник собственных доходов.

Закономерным итогом процесса распада флота и его управленческих структур стал роспуск в 1618 г. Военно-морского совета и его замена Военно-морской комиссией, призванной искоренить коррупцию и восстановить эффективное управление военно-морской сферой. Впрочем, и сама Комиссия также не оправдала возложенных на нее надежд. Итоги ее деятельности весьма сомнительны

С приходом на английский трон Карла I, амбициозного короля, мечтавшего о восстановлении былой мощи страны в качестве ведущей морской державы, изменяется и внешняя политика. Английский военно-морской флот виделся одним из главных инструментов в решении новых внешнеполитических задач. Явные провалы в деятельности Военно-морской комиссии, ее неспособность обеспечить поддержку флота в военных условиях стали причиной ее устранения и воссоздания в 1628 г. Военно-морского совета.

$\mathrm{Ha}$ данный момент деятельность Военно-морского совета в годы правления Карла I исследована очень слабо. Отсутствию большого интереса исследователей к военно-морской истории раннего стюартовского периода есть два главных объяснения. Во-первых, военно-морская история первой половины XVII в. на фоне героического времени Тюдоров выглядит довольно бледно, а флот ранних Стюартов очень часто даже в среде профессиональных историков воспринимается как жалкое подобие могучих «морских стен Ангпии» эпохи Тюдоров. И, во-вторых, значительная часть исторических документов этого периода была утеряна во время событий конца 1640-х - 1950-х гг., и очень маленькое количество фрагментарно сохранившихся документов отпугивает исследователей.

Данная статья посвящена исследованию проблем работы воссозданного Военно-морского совета в годы правления Карла I Стюарта.

Ключевые слова: военно-морской совет, английский флот, военно-морская комиссия, корабли, бюджет, политика, коррупция.

S. N. Gavrilov

\section{THE PROBLEMS OF WORK OF THE MILITARY SEA COUNCIL IN THE YEARS OF THE BOARD OF KARL I STUART}

The Naval Council, which was created in the years of Henry VIII, became the body that effectively provided the permanent work of the English navy. The Navy that turned into the state institute in the Tudor epoch successfully solved the tasks of defense of the country and implementation of its offensive strategy, thereby laying the foundation for the transformation of England into a great sea power. However with the accession to the throne of King-peacemaker James Stewart, the fleet, the "favorite child of the Tudors", became the object of neglect. Under those conditions, corrupt senior officers of the Navy began to consider the collapsing naval system as a source of their own income.

The logical outcome of the process of disintegration of the English Navy and its management structures was the dissolution of the Naval Council in 1618 and its replacement by the Naval Commission, designed to eradicate corruption and restore effective management of the whole naval sphere. However, the Commission itself also did not justify the hopes placed on it. The results of its activities were very doubtful.
The accession of Charles I to the English throne, the ambitious king, who dreamed of restoring the former power of the country as a leading maritime power, led to changes in foreign policy. The English Navy was becoming one of the main tools in solving new foreign policy tasks. Obvious failures in the activity of the Naval Commission, its inability to provide support for the Navy in military conditions caused its liquidation and the restoration of the Naval Council in 1628.

So far the activities of the naval Council during the reign of Charles I have been studied very poorly. There are two main explanations for the lack of interest of researchers in the naval history of the early Stuart period. First, the naval history of the first half of the XVII century in comparison with the heroic time of the Tudors, looks pretty pale and Navy of the early Stuarts very often, even among professional historians is perceived as a pitiful semblance of the mighty "sea walls of Tudor England". And, secondly, a significant part of the historical documents of this period was lost during the events of the late 1640 s-1950s, and a very small number of fragmentary preserved documents deters researchers. 
The article is devoted to the study of the problems of the recreated naval Council during the reign of Charles I Stewart.

Одним из главных достижений английской династии Тюдоров явилось строительство постоянного военно-морского флота, способного решать оборонительные задачи и обеспечивающего реализацию наступательной стратегии Англии. В относительно короткий по историческим меркам срок флот английского короля, собиравшийся и действовавший на феодальной основе, превратился из «события» в постоянно действующий институт. Во многом эти заслуги принадлежали созданному Генрихом VIII и успешно фрункционирующему на протяжении XVI в. Военно-морскому совету.

Однако с восшествием на престол первого представителя Стюартов Джеймса I «любимое детище Тюдоров» стало объектом пренебрежения со стороны власти. Для короля-миротворца военно-морской флот являлся чрезмерной обузой в условиях опустошенной казны. Это привело к тому, что «фолот превратился в ожиревший, безжизненный, вялый организм, разворовывавшийся его собственными служащими» [18, р. 293]. Закономерным итогом стала замена в 1618 г. Военно-морского совета изначально включившей в свой состав двенадцать человек Военно-морской комиссией, в задачи которой вменялось улучшение состояния фолота и искоренение коррупции, разъедавшей организацию управления.

Десятилетняя деятельность Комиссии современниками оценивалась отнюдь не однозначно. Даже мнение Карла Стюарта о ней было весьма противоречиво и колебалось от выражения удовлетворения ее действиями до раздражения и гнева на ее офицеров. Последней каплей для короля, видимо, стала неспособность членов Комиссии обеспечить снабжение действующей эскадры, посланной к расположенному близ Ла-Рошели острову Иль де Ре для помощи гугенотам. Результатом стало рассоормирование в 1628 г. этого административного органа и воссоздание Военно-морского совета (Совета морских дел), просуществовавшего до начала гражданской войны.

Деятельность воссозданного Военно-морского совета в годы правления Карла I на сегодняшний день остается малоизученной, что, в первую очередь, объясняется сложностью проведения исследований из-за лишь фрагментарно сохранившихся источников. Кроме того, на фоне истории военно-морского фллота тюдоровской эпохи, бывшего славными “стенами Англии", героически защитившими страну от порабощения и заложившими основу ее могущества, история военно-морской системы раннего стюартовского периода, как на уровне общественного мнения, так и на уровне профессиональных историков, скорее воспринималась как история ее деградации.

В 1896 г. в свет вышла работа Майкла Оппенгейма «История администрации королевского
Key words: the Naval Council, the British Navy, the Naval Commission, vessels, budget, politics, corruption.

флота» [20], в которой частично затронута деятельность Совета. Но это, пожалуй, первое скрупулезно проведенное исследование военно-морской системы Англии раннего Нового времени за прошедшие сто двадцать лет в силу объективных причин устарело. Что касается более современных трудов, то среди них необходимо, в первую очередь, отметить опубликованную в 1990 г. диссертацию на соискание ученой степени кандидата наук Эндрю Дерека Траша «Военно-морской фллот при Карле |» [41]. Автор ввел в научный оборот значительное количество ранее не использовавшихся документов, хранившихся в отделе рукописей Британской библиотеки и в бывшем Публичном архиве рукописей. Тем не менее, на наш взгляд, это исследование носит местами обзорный характер

Таким образом, деятельность воссозданного Военно-морского совета нуждается в дополнительном изучении.

Итак, восстановленный в 1628 г. Совет в своей структуре несколько отличался от того, что этот орган представлял собой в эпоху Тюдоров. С момента своего создания в 1546 г. он возглавлялся лейтенантом, но эта должность исчезает уже во времена правления Джеймса I. К сожалению, в дошедших до нас документах не содержится каких-либо указаний о причинах ее устранения. Должность этого офицера как главы Военно-морского совета на протяжении второй половиныXVIв. не имела большой функциональной нагрузки и скорее представляла собой некий почетный пост. Учитывая это, ее ликвидация представляется вполне логичной, ибо большой необходимости в сохранении этой должности не было.

И, тем не менее, попытки восстановления этого поста предпринимались. Бывший казначей флота сэр Роберт Манселл безуспешно попытался воссоздать эту должность в 1618 г., но потерпел неудачу. В 1628 г. он уже повторно настаивал на необходимости ее восстановления в возрождающемся Совете морских дел. Пытаясь достичь этой цели, Манселл разработал весьма хитроумную и запутанную комбинацию. Он даже решился умерить свою гордость, всеми силами стремясь замириться со своим врагом Бэкингемом [8]. Но усилия оказались напрасными, убийство Бэкингема привело к краху замыслов коррупционера. Во всей этой истории вызывает удивление то. что Роберт Манселл, имеющий огромный опыт службы в должности офицера Совета на посту его казначея, стремился занять не свою прежнюю должность, а именно пост лейтенанта. Эндрю Траш утверждает, что он просто не осознавал, что эта должность может принести ему лишь титул чести [41, р. 67]. Но с этим утверждением вряд ли можно согласиться. Очевидно, у этого опытного бюрократа, разбогатевшего на корруп- 
ционных схемах фринансовых потоков [21, р. 117119], были совершенно иные мотивы, о которых нам, в силу отсутствия источников, остается лишь догадываться. Возможно, некоторый свет на эту странную настойчивость офицера может пролить тот факт, что в 1618 г. Манселл, согласно распространенной в это время практике, покидая должность казначея, продал ее [18, р. 298-299] Продав ее однажды, он вряд ли мог претендовать на нее снова. Посему бывшему стареющему служащему пост лейтенанта давал именно то, в чем он в данный момент нуждался, а именно почет и место во властной иерархии.

Соотношение четырех оставшихся должностей можно легко проследить, если взглянуть на расположение подписей офицеров Военно-морского совета. Выше других и как можно левее всегда располагалась виза казначея Совета, а затем по убыванию шли подписи контролера, инспектора и клерка военно-морского флота [30]. Расположение росчерков на странице, в целом повторяющее практику тюдоровских времен, дает нам возможность судить об официальном положении офицеров по отношению друг к другу. Но здесь необходимо учитывать и то, что это официальное положение не всегда отражало их реальный вес и влияние. Как и в предыдущее столетие, несмотря на довольно высокий уровень институциализации Совета морских дел, достигнутый уже в середине XVI в., какая-либо подробная документация, регулирующая деятельность этого органа, отсутствовала, и в этих условиях очень многое по-прежнему зависело от личностей, занимающих тот или иной пост.

Пост казначея, первого по положению, в 1628 г получил сэр Сэквил Кроу. Интересно, что патент ему был выдан еще в апреле 1627 г. [20, р. 281] до восстановления Совета морских дел. На должность контролера был назначен сэр Гилфорд Слингсби, имевший определенной опыт работы со времени своей службы в военно-морской администрации в 1611-1618 гг. Место инспектора досталось менее опытному сэру Томасу Айлсбери, являвшемуся секретарем Адмиралтейства с 1619 по 1924 гг. и членом Комиссии в 1626-1627 гг И, наконец, пост клерка получил Дэнис Флеминг, долгое время работавший в составе Комиссии и являвшийся самым опытным членом в составе воссозданного Совета [41, р. 75].

При восстановлении должностей главных офицеров не были устранены недочеты ранее существовавшего Совета, и, в первую очередь, не были письменно зафиксированы обязанности каждого из офицеров. Конкретные сферы ответственности его членов скорее определялись традиционно сложившимся набором обязанностей и их собственным пониманием круга своих полномочий.

Круг обязанностей каждого офицера был установлен и хорошо известен еще со времен создания Совета в 1546 г. Казначей распределял деньги, полученные из различных фондов. Исключением являлись финансы Службы снабжения и Службы вооружений, выпадавшие из сфе- ры его ответственности. ОН также подготавливал и представлял для инспекции все финансовые записи департамента. Контролер, в свою очередь, проверял отчеты казначея и снабженца, проводил аудит записей кладовщиков военно-морского флота, и, кроме всего прочего, видимо, проверял записи инспектора, за точность составления которых он давал свое поручительство на собраниях офрицеров. Инспектор был обязан проводить регулярный осмотр доков, складов и кораблей на местах, надзирать за строительными и ремонтными работами. В его функции включалась и инспекция провизии на складах. Клерк, последний из офицеров, должность которого уходила своими корнями вглубь средневековой эпохи, документировал ход заседаний. Впрочем, на этом его обязанности не ограничивались, ибо он действовал еще и как поставщик, и, помимо всего, отслеживал динамику цен, о которой докладывал остальным офицерам.

Единственная попытка хоть как-то очертить круг обязанностей членов Совета для того «чтобы они знали, что они должны делать и за что нести ответственность перед страной», была предпринята в 1560 г. [14, р. 165]. Впрочем, вряд ли в этом случае можно говорить о жесткой фиксации обязанностей, их границы оставались размыты и в общих словах всего лишь подтверждали уже существующие реалии.

В годы большей стабильности, например, в елизаветинское время, отсутствие фиксированных обязанностей не порождало каких-либо действительно серьезных затруднений, поскольку каждый из членов Совета имел ясное представление о круге своих полномочий. Более того, при определенных условиях отсутствие письменной фиксации обязанностей давало возможность офицерам проявлять инициативу. Подобная свобода действий в годы политической турбулентности середины XVI в. явилась одной из причин того, что Военно-морской совет оставался едва ли не единственной управленческой структурой, не только поддерживавшей стабильное функционирование той сферы, за действия которой он отвечал, но и обеспечивавшей ее дальнейшее развитие [1, с. 106]. Но реализация такого потенциала была возможна лишь при условии, что во главе ведомства стоит круг профессионалов и единомышленников, радеющих, в первую очередь, не столько о личной выгоде, сколько о флоте, или, по крайней мере, в поисках личной выгоды не забывающих и нужды флота. В тюдоровскую эпоху офицеры Военно-морского совета во многом воспринимали свои должности как держания. С одной стороны, они считали возможным использовать представляющиеся им возможности для личной выгоды, но, с другой, они часто жертвовали личными средствами. Уильям Монсон в Военно-морских трактатах, перечисляя идеальные качества казначея флота, упоминает и способность «внести большую сумму денег для спокойствия Его Величества и удовлетворения подчиненных, которые иначе будут ворчать и требовать свое жалованье после проделанной работы» $[40$, p. 416$]$. 
Однако, примеры такого «самопожертвования» в истории первой половины XVII в. наблюдаются довольно редко. В годы нестабильности, дезорганизации власти и противостояния различных политических сил моментально возрастала опасность борьбы в военно-морской администрации за те или иные властные полномочия. И именно такая ситуация характерна для 1630-хгг Одну из причин злоупотреблений кассир фрлота Джон Холлонд объяснял в 1638 г. тем, что было нелегко определить обязанности каждого офицеpa [42, р. 10]. На практике это часто приводило к внутренним столкновениям.

Некоторые затруднения для работы Совета составляло отсутствие постоянного места встреч. Необходимость в таких встречах была велика, ведь Совет являлся коллегиальным органом. Его члены несли ответственность за действия друг друга. Несмотря на неравенство их статусов, офицеры принимали решения на основе голосования по большинству, ибо «ни один человек не должен иметь перевес над своими товарищами" [7]. Встречи, согласно установленным еще в тюдоровское время нормам, должны были проходить не реже двух раз в неделю, ведь рутинная работа по поддержанию флота и его инфраструктуры не должна была останавливаться. Впрочем, малое число дошедших до нас фрагментарно сохранившихся документов не дает возможность делать выводы, что такие встречи действительно регулярно проводились.

Необходимость обеспечения постоянным местом встреч офицеров была головной болью властей. В 1628-1629 гг. для этих целей был снят дом на Сент Мартин лэйн в центре Лондона. Это место имело весьма удобное расположение, но, возможно, возникли трудности со съемом [12], и, видимо, по этой причине в следующем году Совету был предоставлен дом на Минсинг Лэйн, рядом с Тауэром и неподалеку от Службы снабжения [9]. Сам дом был очень удачно расположен, но новое место встреч было крохотным. Даже свои записи каждый из членов Совета вынужден был хранить дома, а казначей, например, предпочитал использовать другой дом на Тауэр Стрит, которым до 1637 г. он владел, либо же снимал его за собственные деньги [23].

В 1633 г. вопрос вновь оказался в повестке дня. «В целях упорядочивания записей военно-морского фллота» рассматривалась возможность перемещения места заседаний офицеров и хранения всех документов в бывшее цистерианское аббатство Святой Марии Грации на Тауэр хилл. Но переезд так и не состоялся, и проблема не была решена.

Впрочем, отсутствие постоянного места встреч главных офицеров не являлось действительно такой уж значимой проблемой. Так или иначе, она не была препятствием в работе Совета в предыдущие годы.

Гораздо большее удивление вызывает другой факт. Ни один из вышеупомянутых служащих, видимо, не вызывал большого доверия у властей. Каждый из них, в той или иной степени, успел к моменту получения новой должности запятнать себя на прежней службе. И в этом отношении их назначение могло привести к большим трудностям в работе столь важного органа. Так Сэквил Кроу, хоть и был казначеем флота еще во времена существования Комиссии, но по неизвестной причине в ее состав включен не был. Уже в июне 1629 г. исполнение его обязанностей было приостановлено, так как он попал под подозрение в расхищении фондов. И хотя спустя месяц ему разрешили вновь приступить к работе, Кроу внезапно уезжает, а на его место назначается другой. В таком окончании службы нет ничего удивительного. Для Англии этого времени подобный финал был вполне обычным явлением. Именно так чаще всего без скандалов и обвинений позволяли покинуть свой пост проштрафившимся служащим [27].

Не меньшее удивление вызывает и назначение Гилфорда Слингсби, человека, отличавшегося чрезвычайно склочным характером. Он не только постоянно создавал проблемы для своих сослуживцев на своем прежнем месте службы $[41$, p. 86], но и давал большое количество поводов сомневаться в своей честности. Слингсби был настоящим задирой и являлся постоянным участником ссор. На его фоне назначение его младшего сослуживца Томаса Айлсбери, не имевшего большого опыта и гораздо более тихого по своему характеру, вряд ли могло вызвать большие опасения. Но, как вскоре оказалось, и он не был лишен амбиций. Именно Айлсбери в 1630 г., к удивлению многих, вдруг в явно ультимативной форме потребовал признания своего старшинства в Совете [41, р.68], породив большой скандал.

Пожалуй, из всех служащих клерк Дэнис Флеминг был наименее замешан в коррупционных схемах, но в раннее Новое время эта должность, в отличие от Средневековья, не была сопряжена с большими полномочиями. Более того, в XVII в. все чаще раздавались голоса в пользу выведения этой должности из Совета, поскольку она не была непосредственно связана с исполнительными функциями власти [41, р. 68].

Таким образом, возникает вопрос о том, почему, несмотря на свою репутацию и довольно неуживчивый характер, все эти люди получили назначение в Совет? Даже учитывая определенный дефицит талантливых управленцев во время правления Карла І, в 1628 г. можно было подобрать и более подходящие кандидатуры, и, более того, некоторые из этих вероятных кандидатов также имели значительный опыт административной деятельности в Военно-морской комиссии. Среди них, например, можно отметить сэра Джона Кока, входившего в ее состав. Способности и рвение этого человека были замечены, и в сентябре 1625 г. он был назначен государственным секретарем, не переставая, однако, числиться членом Комиссии и играть в ней первую роль. Его честность и неподкупность не вызывала сомнений. Возможно, по этой причине он в декабре 1626 г. был назначен в состав специальной ко- 
миссии по изучению эфффективности деятельности своих коллег [36].

Размышляя о странности этих назначений, необходимо учитывать ряд взаимосвязанных между собой обстоятельств: коррупцию, фракционность политики и патронаж. Рассуждая о разъедающей фрлот коррупции, мы должны учитывать то, что использование своего положения в личных целях в описываемое время было вполне распространенным явлением. Так, например, в Англии насчитывалось от 5000 до 10000 чиновников. занятых в сфере управления государством, что было значительно меньше в пересчете на душу населения, чем во Франции [2, р. 170-172]. Но при этом частые расследования Короны и постоянные парламентские дебаты в период правления первых Стюартов свидетельствуют о необычайно сильном размахе коррупции. Довольно часто на том или ином посту оказывались люди, воспринимавшие свои должности как синекуры, как некую возможность пополнить свое состояние, при этом само понимание нелегальности реализации коррупционных схем зачастую в их головах отсутствовало. Нельзя сказать, что власть не осознавала пагубность подобной практики и не пыталась с ней бороться. Меры, безусловно, предпринимались, о чем свидетельствует деятельность упомянутого Джона Кока. Но власть, видимо, часто вынуждена была мириться с этим положением. По меткому замечанию Линды Пек, в раннестюартовском военно-морском флоте "сила синекур являлась сухожилиями власти» $[21$, p. 108]. В этом отношении весьма красноречивы слова клятвы контролера военно-морского флота, в которой он обещал нести свою «службу руководствуясь целями получения наибольшей выгоды для его Величества, и ни при каких обстоятельствах не стремиться к получению собственной выгоды путем нанесения убытков его Величеству» [19]. Как видим, получение собственной выгоды на службе вовсе не исключалось, она лишь не должна была наносить вред королю.

При назначении на должность в XVI-XVII вв. значительную роль играла фракционность. Фракционность и патронаж способствовали фрормированию условий для коррупционной практики, но они же были и одним из главных инструментов ресорм во флоте [21, р. 106-107]. Высокий уровень фракционности отмечается уже во времена Тюдоров [17, р. 13-24]. Ситуация во власти при первых Стюартах, в том числе в сфере управления флотом, бывшей второй по размерам после королевского двора, дает нам повод говорить лишь об увеличении степени фракционности. Вскоре после убийства герцога Бэкингема в попытке повлиять на короля с целью проведения своего ставленника на должность лорда-адмирала Англии столкнулись две влиятельные группировки. Одним из претендентов был Генри Рич, граф Холланд, за которым стояла профранцузская партия, получавшая помощь от французского посла. Его соперником являлся Джеймс Хай, граф Карлайл. Обе фракции действовали через королеву, ставшую после смерти Бэкинге- ма наиболее влиятельной фиигурой в окружении Карла [41, р. 24-25]. Король, впрочем, не собиравшийся устранять Комиссию Адмиралтейства, заменившую Бэкингема, умело подогревал это противостояние, распространяя через своих приближенных слухи, и, тем самым, сохранял фракционность. Без сомнения, эти фракции в будущем оказывали сильное влияние на работу Комиссии Адмиралтейства, заменявшей лорда-адмирала, а через Комиссию и на Военно-морской совет.

Неустойчивость состава Военно-морского совета во времена правления Карла I стала, отчасти, результатом неудачно подобранных главных офицеров. Уже вскоре после его воссоздания последовало отстранение Кроу от должности казначея, полномочия и обязанности которого временно перешли к Гилфорду Слингсби, продолжавшему занимать должность контролера, и к Кенрику Эдисбери, советнику и ассистенту флота, выполняющему административные функции на местах $[15$, р. 582]. Эдисбери, ценимый за свою работоспособность и честность, оказался перегружен работой. Таким образом, эта временная замена не могла стать решением проблемы.

Возвышение казначея началось еще в елизаветинскую эпоху во времена реформ казначея флота Джона Хоукинса. Он, по сути, стал тем офицером, который благодаря прямой подчиненности лорду-казначею Англии получил широкие полномочия и контролировал практически все финансовые потоки. Слинсгби же не пользовался доверием, отдавать в его руки финансы флота было довольно опасно. Что касается Кенрика Эдисбери, то он был необходим для работы на местах, поскольку хорошо разбирался в особенностях службы. Не случайно в январе 1630 г. он был восстановлен в некогда занимаемой им должности кассира, выплачивающего деньги, получаемые из центра, за конкретные работы в портах и доках. Интересно то, что снятие с должности кассира Эдисбери в апреле 1627 г. и возвращение его на эту должность в январе 1630 г совпадает по времени с отставкой и новым назначением Уильяма Рассела в качестве казначея. Учитывая это, вполне возможно предположить, что Эдисбери был, если не креатурой, то правой рукой Рассела, человеком, которому работоспособный казначей всецело доверял.

В итоге в январе 1630 г. патент на должность получил бывший член Военно-морской комиссии Уильям Рассел [20, р. 281]. Проблема осложнялась тем, что к этому времени он был тяжело болен. Причем этот фракт был широко известен, ибо именно обострившаяся подагра в 1627 г. вынудила его уйти в отставку [5; 6]. Болезнь быстро прогрессировала, в 1632 г. Рассел уже не мог стоять на ногах, а к 1638 г. у него полностью отказали ноги и руки. Несмотря на это, он проявлял редкое усердие. Подобно многим служащим предшествующей эпохи, Уильям Рассел часто тратил на выполнение обязанностей казначея свои личные денежные средства, получаемые им в качестве дохода от одновременного занятия других должностей [3, р.93 - 94]. Более того, к нему доволь- 
но хорошо относились его сослуживцы. Будучи уже тяжелобольным человеком, Рассел, как мог, продолжал исполнять свои обязанности. В январе 1639 г. ему в помощь был назначен «товарищ казначея» Генри Вэйн [35]. Назначение «товарищей» в качестве соисполнителей, видимо, именно в это время стало входить в практику по причине неспособности многих офицеров выполнять свои обязанности. Молодой Вэйн, которому в этот момент было всего двадцать шесть лет, хотя и являлся трудолюбивым служащим, так и не смог снискать уважение в кругу офицеров. Его, постепенно вытеснявшего старого Уильяма Рассела, воспринимали как зазнайку и выскочку.

Недолго продержался на посту контролера и сэр Гилфорд Слингсби. Его склочность и непомерное желание ставить себя выше других вскоре надоели всем. В итоге в апреле 1631 г. он был заменен сэром Генри Палмером. Не будучи старым, в свои сорок девять лет Палмер отличался весьма слабым здоровьем, состояние которого часто не позволяло ему исполнять свои обязанности. Любой выезд из дома превращался в личный подвиг, поскольку грозил вызвать рецидив подагры. И хотя он всячески крепился и изо всех сил старался скрывать свою болезнь, в 1638-1639 гг она практически приковала его к постели. Отчаявшись вернуться к службе, он согласился разделить свои обязанности с молодым Джорджем Картеретом [41, р. 81]. В 1641 г. он окончательно передал свой пост в руки Картерета [38].

Схожая ситуация сложилась и с должностью инспектора. Томас Айлсбери, хоть и являлся секретарем адмиралтейства с 1619 по 1924 гг., а также входил в состав комиссии в 1926-1927 гг., особым опытом похвастаться не мог. Айлсбери беспокоило скорее не состояние флота, а его личный статус среди сослуживцев. Вскоре после своего назначения он демонстративно поставил под сомнение старшинство казначея в Совете и потребовал признать свое главенство на том основании, что он единственный из всех имел титул барона. Случилось это примерно в то время, когда был отстранен Кроу. Необходимо признать, что определенные моральные права требовать старшинства у Айлсбери все-таки были, поскольку Слингсби, временно поставленный исполнять обязанности казначея, вряд ли имел больший опыт управления, да и его замешанность в коррупции позволяли поставить под сомнение легитимность его назначения. Что касается Эдисбери, второго исполняющего обязанности казначея, то он вообще не являлся членом Совета. Таким образом, Айлсбери избрал весьма удобный момент для атаки, но слишком переоценил свои силы и влияние. Его требования просто остались без внимания. Оскорбленный до глубины души он весной 1631 г. решается на рискованный маневр и передает большинство дел своему старшему клерку Натаниэлю Тирну [31]. Это был скорее демонстративный шаг, ибо сам инспектор рассчитывал, что клерк будет посылать ему отчеты, и, таким образом, опасность потери контроля над своим прежним постом не возникнет. Тирн же, как оказалось, не смог исполнять обязанности инспектора. В итоге неспособность Тирна к работе в этой должности, интриги и упрямство Айлсбери, стремившегося показать свою незаменимость, привели лишь к тому, что проведение всех инспекций практически было остановлено.

Выстраивая хитроумные комбинации, Айлсбери обыграл сам себя. Как и следовало ожидать, итогом стала его отставка. В декабре 1632 г. он был заменен Кенриком Эдисбери [20, р. 281], тем самым служащим, которого прежний инспектор даже не брал в расчет. Эдисбери, пожалуй, был самым исполнительным и энергичным из всех главных офицеров [20, р. 281]. Неутомимый служащий постоянно был переполнен новыми идеями о повышении эффективности выполняемой работы, и хотя его специальные знания были ограничены, он часто предлагал возможные пути улучшения инспекции [41, р. 85]. На своем посту он оставался до своей смерти, наступившей, предположительно, в результате застарелой болезни в октябре 1638 г. Без сомнения, военно-морской флот со смертью Кенрика Эдисбери понес значительную утрату.

Последовавшее за этим новое назначение Уильяма Баттена [20, р. 281] довольно интересно. Патент на назначение он получил не с формулировкой «пожизненно», а с весьма интересной формулировкой «на столь долго, на сколь будет угодно» королю [20, р. 282]. Эта практика назначений офицеров военно-морского фллота и Службы вооружений ранее не применялась и получила широкое распространение после издания приказа от 13 января 1637 г.

Более других из главных офицеров первой волны в своей должности продержался клерк Дэниз Флеминг. Он был довольно работоспособен, не был склонен к скандалам и склокам и избегал участия в интригах своих сослуживцев. Однако состояние и его здоровья оставляло желать лучшего. И хотя, в отличие от своих коллег, в силу особенностей его обязанностей, он вынужден был гораздо реже покидать Лондон, но выполнять свою работу ему становилось труднее и труднее. Так что вопрос поиска новый кандидатуры на должность клерка с годами вставал все острее. Сам Флеминг, не будучи включен в список служащих, имеющих право получать пенсию от короля, не проявлял желания добровольно уйти со своего поста даже после назначения в январе 1638 г его товарищем Томаса Барлоу, служащего графа Нортумберленда [16, р. 195]. Примерно в это время он в обмен на денежную выплату попытался передать свой пост служащему при королевском дворе своему другу Фрэнсису Уильямсону [41, р. 79], однако коллеги Флеминга заявили решительный протест. Придворных не особо жаловали в военно-морской сфере. Передача власти не состоялась, поэтому престарелый и больной, но упорный Флеминг продолжал исполнять свои обязанности вплоть до своей смерти в 1639 г.

Во всей этой истории постоянной смены офицеров в воссозданном Военно-морском совете отчетливо выделяются два этапа, водоразделом 
между которыми являются 1630-1632 гг. Именно в это время лишились своих должностей три из четырех изначально назначенных главных офицеров. И эта дата далеко не случайна.

Сохранившиеся документы не дают нам основания говорить о продуманности решения Карла Стюарта распустить Военно-морскую комиссию и воссоздать Военно-морской совет. По крайней мере, его отношение к деятельности Комиссии нельзя назвать исключительно негативным В ее действиях было довольно много недостатков, но также были и достижения. И Карл, хотя и не будучи сам хорошим моряком, подобно Генриxy VIII, тем не менее, был человеком, любившим военные корабли и прекрасно осознававшим значение военного фрлота. Король стремился проводить активную внешнюю политику, и военно-морским силам отводилась роль ее главного орудия. C самого начала своего правления Карл настаивал на том, что обладает всеми правами на Британские воды [22, р. 160-163]. Пренебрежение к кораблям, подобное тому, что наблюдалось в начале правление его отца, он позволить себе не мог. Монарх также не мог не замечать, что деятельность Комиссии с момента ее создания в 1618 г. приносит плоды. В ходе расследований были вскрыты ужасающие факты коррупции, процветание которой происходило во многом благодаря бывшему казначею Совета морских дел сэру Роберту Манселлу и инспектору сэру Джону Тревору, пользующимся покровительством и защитой престарелого лорда-адмирала Чарльза Говарда, графа Ноттингема [21, р. 122-126]. Многие служащие, включая самого лорда-адмирала, лишились своих постов, а их места заняли люди, более внушающие доверие, такие как старший член Комиссии Джон Кок. Ко времени вступления на престол Карла I в 1625 г. военный флот насчитывал двадцать пять больших кораблей и несколько пинас, представлявших собой малые парусно-гребные суда [24]. Такое количество военных судов во времена правления Елизаветы Тюдор считалось вполне достаточным, при условии, что система привлечения многочисленных частных военных сил работает эфффективно. Джон Кок писал: «Флот был сильнее, чем когда-либо на моей памяти, и его мощь выше, чем в прежние времена» [4]. В этих достижениях, без сомнения, велика была личная заслуга лорда-адмирала герцога Бэкингема, но трудно себе представить, что без участия Комиссии такой результат был бы достижим

Таким образом, создается впечатление, что в расформировании в целом не так уж и плохо зарекомендовавшей себя Комиссии 21 февраля 1628 г. и воссоздании Совета значительную роль сыграли эмоции Карла І. И действительно, король был не просто раздосадован тем, что очень важная экспедиция к Иль де Ре закончилась провалом, он еще и испытывал стыд перед лордом-адмиралом Бэкингемом, у которого просил прощение за задержку отправки припасов силам герцога, ссылаясь на медленную работу членов Комиссии $[41$, р. 74]. Короля связывали с герцогом очень близкие отношения. Их сотрудничество и партнерство начали фрормироваться задолго до коронации Карла. Будучи принцем, он демонстрировал заметную заинтересованность кораблями и флотом. Джеймс I, заметив это, всячески поощрял своего сына и герцога в 1619-1624 гг. работать вместе над проектом военно-морских реформ, проведение которых было необходимо после отставки лорда-адмирала Ноттингема [22, р. 159].

Оставшиеся четыре человека, т.е. треть от изначального состава Комиссии, действительно не смогли обеспечивать поддержку фрлота. Но это вовсе не означает, что людей было недостаточно для выполнения такой задачи, ведь в тюдоровское время Совет морских дел, насчитывавший в своем составе пять человек, с успехом справлялся и с куда более масштабными задачами. Обращает на себя внимание и то, что воссозданный Совет состоял из такого же количество служащих, т.е. четырех человек, причем три из них имели далеко не блестящую репутацию. Учитывая все эти обстоятельства, вывод напрашивается сам собой. Очевидно, Карл, переполненный эмоциями, просто сорвал свой гнев на членах Комиссии, устранив попутно и сам орган.

Что касается Совета, то уже несколько месяцев спустя Бэкингем выражал сожаление по поводу восстановления постов главных офицеров, поскольку они «в своих представлениях стояли выше своих должностей, но при этом были неспособны исполнять то, что необходимо из-за недостатка понимания в этих делах" [8]. В его словах прослеживается сожаление не столько по поводу воссоздания Совета, сколько по поводу личной некомпетентности его членов. Отсутствие улучшения ситуации подтверждает и секретарь Совета Николас в своем письме к Коку: «Небрежность и невежество офицеров военно-морского флота стали главными причинами того, что фрлот и припасы не были подготовлены» [7].

Между тем, сам Карл также, вероятно, не был вполне доволен состоянием военно-морских сил. В октябре 1630 г. он попросил одного из членов Комиссии Адмиралтейства Джона Кока составить отчет о флоте [28]. И хотя в этой просьбе видна не только тревога о Военно-морском совете, но и беспокойство по поводу работы Комиссии Адмиралтейства, заменившей лорда-адмирала, однако неутешительный вывод Кока о работе военно-морских баз не мог не поставить под удар Военно-морской совет. Именно последний, а вовсе не Комиссия Адмиралтейства отвечал за техническую работу на местах. Кок не замедлил обрушиться с критикой на Совет. В Чатхэме, например, одной из главных баз флота, судя по описаниям проверяющего, ситуация была ужасной. Деревянная изгородь полностью сгнила, замки на воротах разбиты, припасы отпускаются без каких-либо распоряжений, оставшееся на складах не учтено, корабли столь долго простаивают в сухих доках, что их трюмы прогнили [11].

В марте 1631 г. Кок набросал список предложений для реформирования Совета. Они были выпущены как сборник адмиральских инструкций в следующем месяце. К сожалению, на данный мо- 
мент этот сборник утерян. Как полагает Э. Траш, именно данный список предложений лег в основу исчезнувших адмиралтейских инструкций, выпущенных в середине апреля, в которых содержался приказ главным офицерам «реформировать и улучшать их работу" [26]. Этот вывод, считает исследователь, подтверждается письмом, написанным главными офицерами в июле $1631 \Gamma_{\text {., }}$ в котором явно отражается мартовский отчет по флоту [41, р.90]. Письмо также подтверждает, что усилия Кока не сказались напрасными, поскольку оно адресовалось хранителю складов в Дептфорде и клерку контроля и требовало от них принять меры для реформирования базы фрлота [10].

На Джона Кока выбор пал отнюдь не случайно. В свое время возглавлявший Военно-морскую комиссию, он получил большой опыт работы в сфере военно-морского администрирования. После смерти Бэкингема и создания Комиссии Адмиралтейства он, будучи секретарем лорда-казначея Англии Ричарда Уэстона, графа Портленда, вошел в ее состав. И хотя возглавлял этот орган сам лорд-казначей, но опыт Кока в военно-морской администрации признавался всеми безоговорочно. В декабре 1628 г. члены Комиссии писали своему секретарю Эдуарду Николасу «Для улучшения ведения дел приносите на подпись все письма и приказы сначала Коку, а после этого и остальные лорды подпишут эти бумаги» [29]. В 1630-х гг. партнеры Кока в комиссии доверяли ему проведение постоянных встреч с главными офицерами ффлота для обсуждения смет [37; 34]. Учитывая это, вовсе не удивительно, что ближайший советник короля Томас Уэнтворт описывал военно-морской флот как «возлюбленную» Кока [39].

В том, что Кок не станет скрывать недостатки, сомнений не было. Поскольку он являлся правой рукой лорда-казначея Англии, на данном этапе практически и возглавившего всю военно-морскую систему посредством контроля финансов, его главной задачей была экономия средств. И Джон Кок отлично понимал, как это сделать наилучшим образом. Стоит упомянуть, что тенденция постоянной борьбы Казначейства с Адмиралтейством из-за попыток установить контроль над Военно-морским советом прослеживается на протяжении всей предшествующей истории его существования. С момента своего создания в 1546 г. Совет номинально подчинялся лорду-адмиралу. В годы рефформ казначея фолота Джона Хоукинса, ставшего в конце 1570-х гг. главной фигурой в этом органе, Совет контролировался лордом-казначеем Уильямом Сесилом бароном Бэрли. Но после смерти Бэрли в 1598 г. Совет вновь номинально попадает под контроль лорда-адмирала. Это состояние продолжалось до смерти в 1628 г. герцога Бэкингема и назначения вместо лорда-адмирала Комиссии Адмиралтейства, в которой главную роль играл лорд-казначей Англии Ричард Уэстон граф Портленд. Учитывая это, было бы ошибочно утверждать, что Джон Кок являл собой образец абсолютно беспристрастного эксперта. Так, например, некоторое время спустя Эдуард Николас заявил: «Ни казначей, ни кто-ли- бо из Казначейства не подходят для того, чтобы быть членом Комиссии Адмиралтейства» [32].

Но, так или иначе, перемены начались. Кок, ставший главным двигателем этих изменений, положил им начало за несколько месяцев до своего отчета. Именно в этом ключе можно рассматривать все замены в составе Совета в 16301632 гт, и, прежде всего, попытку включения в его состав Эдисбери. Но простой замены недееспособных офицеров для улучшения ситуации было явно недостаточно. Необходимо было включить в состав Совета верных себе людей, пусть даже они и не будут занимать одну из традиционных должностей. На пост нового «офицера без портфеля», в феврале 1630 г. был отобран бывший член Военно-морской комиссии Уильям Барелл $[41$, р. 78]. Он не занимал в Совете офицциальной должности с определенным кругом обязанностей, однако, имел право голоса на заседаниях и выполняет отдельные поручения. Впрочем, Барелл так и не успел оправдать надежд Кока по причине своей внезапной смерти. Его заменили друг Кока опытный военно-морской командующий и дипломат Кенельм Дигби и включенный в состав по приказу короля корабельный мастер Пинеас Питт. Возможно, именно Дигби ставший главным агентом государственного секретаря, помог ему подготовить мартовский отчет. Но и Кенельм Дигби оставался в составе Совета лишь до 1633 г., пока не был отозван, возможно, по причине стремительно распространявшихся в обществе слухов о причастности к смерти его жены, в мае 1633 г расставшейся с жизнью. Питт же и далее номинально числился членом этого органа, состоящего теперь из пяти членов.

Немного ранее, в 1630-м г. офицеры Совета получили инструкцию включить главу Службы снабжения флота сэра Сэмпсона Даррелла «в свое сообщество» [25]. Впрочем, вряд ли мы можем говорить, что он являлся агентом Кока. Скорее попытка его включения в состав Совета объясняется необходимостью упрощения слаженной работы всей флотской администрации. Эта версия выглядит весьма правдоподобно, учитывая то, что практика совместных заседаний главы снабжения с другими служащими была обычным делом в годы существования Военно-морской комиссии, членом которой этот офицер и являлся. Но удивительно то, что ни в одном из известных на сегодняшний день документов подпись Даррелла среди подписей других офицеров не обнаруживается. Опираясь на этот фракт, можно предположить, что вскоре после выпуска инструкции она была отменена. Но гораздо более интересную версию предлагает Эндрю Траш, высказывающий предположение, что офицеров просто попросили проявить обычное сердечное дружелюбие к Дарреллу [41, р. 69].

Дошедшие до нас документы не дают свидетельств в пользу активности новых членов Совета по поддержанию работы фллота. Это подтверждает версию о необходимости их участия для того, чтобы контролировать остальных. Безусловно, главные офицеры понимали это, и, 
учитывая бездействие своих новых товарищей постоянно протестовали против их присутствия отказываясь признавать их в качестве равных себе. В 1634 г. раздраженный контролер заявил что «хотя Питт имеет власть офицера и исполняет его обязанности, по своей природе он всего лишь ассистент» [33].

Впрочем, утрата Кенельма Дигби не означала что Кок потерял контроль над Военно-морским советом. Правой рукой государственного секретаря и поставщиком всех сведений о работе офицеров являлся Эдисбери. Уже вскоре после своего назначения он раскрыл, что Палмер, Флеминг и Питт выстроили отлаженную систему воровства и продажи старых канатов производителям бумаги. Эта система опиралась на разветвленную сеть служащих в доках [41, р. 92]. Разгорелся большой скандал, известный как «дело коричневой бумаги».

Таким образом, смена в 1630-1632 г. главных офицеров фолота частично смогла исправить ошибки, совершенные при восстановлении Совета морских дел. Новая волна офицеров, хоть и отличавшихся болезненностью, все-таки была более профессиональна и продолжала работать до конца $1630-x$ гт.

Что касается результативности их работы, то ее оценивать однозначно довольно сложно по нескольким причинам.

Военно-морской совет времен Карла I не имел такую самостоятельность, какую он имел во времена Тюдоров. В момент своего воссоздания он находился под сильным контролем лорда-адмирала герцога Бэкингема. Герцог, по сути, лично стоял во главе всей военно-морской системы, в значительной мере определяя стратегию ее развития. Король, отдавая должное талантам своего лорда-адмирала, даже не пытался вмешиваться.

После же смерти герцога английский фолот в целом и Военно-морской совет в частности находились под контролем Карла I и Комиссии
Адмиралтейства, главную роль в которой играл лорд-казначей Портленд. Политика Портленда сводилась к жесткому ограничению бюджета флота. В условиях слабого фринансирования говорить об успешности работы Совета не приходится. И все-таки даже в это тяжелое для флота время, благодаря деятельности Джона Кока, была осуществлена программа строительства новых кораблей. К 1634 г. четыре новых военных корабля вошли в строй, и было объявлено о строительстве нового огромного корабля «Sovereign of the Seas», киль которого был заложен в Вуличе [22, p. 70]

И лишь в середине 1630-х гг. жесткая хватка лорда-казначея над флотом ослабевает. Введение корабельных денег предоставило новые возможности развития. К этому времени английский военно-морской флот действительно представляет собой внушающую уважение силу, он постоянно присутствует в проливах. Двадцать с лишним тяжеловооруженных английских военных кораблей, сопровождаемые множеством более легких судов, не только контролировали пролив, но и доходили до Бюкан Несс на севере и до Бискайского залива на юге. Они являлись грозным предостережением как французам и испанцам, так и непокорным голландцам. Организация и огневая мощь этих фрлотов была куда выше огневой мощи и организации флотов 1620-х гг. Богато украшенный и имеющий знаковое имя 1500-тонный Sovereign of the Seas, спущенный осенью 1637 г., стал в подлинном смысле первым трехпалубным кораблем, по своему тоннажу, длине, вооружению, конфигурации парусов стоявший гораздо ближе к кораблям Нельсона, чем к военным кораблям Дрейка

К несчастью для Карла вся эта мощь так и не была задействована в сражениях, ибо его внешняя политика к этому времени уже «села на мель).

\section{Источники и литература / References}

1. Гаврилов С. Н. Английский флот эпохи Тюдоров как государственный институт. Ростов-на-Дону, 2014. 204 с.

Gavrilov S. N. Angliiskii flot epokhi Tyudorov kak gosudarstvennyi institut (The English Navy of the Tudor Time as a State Institution). Rostov-na-Donu: SFU publ., 2014. 204 p.

2. Aylmer G.E. Bureaucracy // The New Cambridge modern history / Ed. by Burke P. Cambridge, 1979. Vol. XIII. P. 164200.

3. Aylmer G. E. The King's Servants. L., 1961. 527 p.

4. British Library. Additional MS. 64889, fo. $155 \mathrm{v}$. Sept, 1626.

5. British Library. Additional MS. 64889. fo. 67

6. British Library. Additional MS. 64896. fo. 90

7. British Library. Additional MS. 64897. fo. 9.1628. 2 July. Nicholas to Coke.

8. British Library. Additional MS. 64897. fo. 11. 1628. 3 July. Nickolas to Coke

9. British Library. Additional MS. 9297. fo. 178. 1630. 16 March. Admiralty to Principal Officers

10. British Library. Additional MS. Uncatalogued. 1631. 25 July. Principal Officers to John Wells and Edward Falkener.

11. British Library. Egerton MS. 2541. fos. $174-80$

12. British Library. Harleian MS. 1649A. fo. 116v. Payment to Richard Alport

13. British Library. Sloane MS. 3232. fo. 141.

14. Calendar of State Papers. Domestic Series. 1547-80 / Ed. by R. Lemon. L., 1856. 802 p.

15. Calendar of State Papers. Domestic Series. 1628-29 / Ed. by J. Bruce. L., 1859. 714 p.

16. Calendar of State Papers. Domestic Series. 1637-38 / Ed. by J. Bruce. L., 1869. 718 p.

17. Ives E. W. Faction in Tudor England. L., 1989. 28 p.

18. Kenny R. W. Elizabeth's Admiral: the Political career of Charles Howard, earl of Nottingham, 1536-1624. Baltimore 1970. $354 \mathrm{p}$ 
19. Magdalene College. Cambridge. Pepys MS. 2876. P. 653

20. Oppenheim M. A history of the Administration of the Royal Navy. L., N.Y., 1896. 444 p.

21. Peck L. L. Court patronage and corruption in early Stuart England. Cambridge., 1990. P. 117-119. $319 p$

22. Quintrell B.W. Charles I and his Navy in the 1630's // The Seventeenth century. 1988. № 3. P. 159-179.

23. The National Archives. Exchequer. 351/2279. Payment to Thomas Salter.

24. The National Archives. State Papers. 16/13/59.

25. The National Archives. State Papers. 16/156. fo. 61.

26. The National Archives. State Papers. 16/156. fo. 67v. n.d. Included List of lost books

27. The National Archives. State Papers. 16/158/44. A Letter by the Lord Treasurer to the Attorney-General in Jan 1630

28. The National Archives. State Papers. 16/174/21. 1630.10 Oct. Coke to Nicholas.

29. The National Archives. State Papers. 16/177/176. 1628. 13 Dec.

30. The National Archives. State Papers. 16/183/2. 1631. Jan. Russel to Admiralty.

31. The National Archives. State Papers. 16/188/76. Admiralty agenda. 1631. 16 April.

32. The National Archives. State Papers. 16/256/21/.

33. The National Archives. State Papers. 16/258/27. Reasons for increasing the Comptroller's of salary submitted to the Admiralty. 1634. 7 Jan.

34. The National Archives. State Papers. 16/282/34. 1635. 11 Jan, Cock to principal officers

35. The National Archives. State Papers. 16/425/46. 1639. 10 July. Nicholas to Pennington.

36. The National Archives. State Papers. 16/45. fo. 3.

37. The National Archives. State Papers. 16/475. fos. 321, 323v. 1633. 21 Dec, 1634. 18 Jan. Meetings.

38. The National Archives. State Papers. 16/485/113. 1641. 25 Nov. Carteret to Pennington

39. The National Archives. State Papers. 63/256/19. 163711 March.

40. The Naval Tracts of Sir William Monson in six books / Ed. by M. Oppenheim. Vol. IV. Navy Record Society, 1913. $446 \mathrm{p}$.

41. Thrush A. D. The Navy under Charles I. 1625-1640. PhD. dissertation. University College, 1990. 384 p.

42. Two Discourses of the Navy 1638 and 1659 by John Hollond and Discourse of the Navy 1660 by Sir Robert Slyngesbie / Ed. by Tanner J.R. Cambr., 1896. 419 p.

\section{Сведения об авторе}

Гаврилов Сергей Николаевич - кандидат исторических наук, доцент кафедры зарубежной истории и международных отношений института истории и международных отношений Южного федерального университета (Ростов-на-Дону) / serggavr75@mail.ru

\section{Information about the author}

Gavrilov Sergey - PhD in History, Associate Professor, Chair of Foreing History and International Relations, Institute of History and International Relations, North-Caucasus Federal University (Stavropol) / serggavr75@ mail. ru 